\title{
What determines levels of passive smoking in children with asthma?
}

\author{
Linda Irvine, Iain K Crombie, Roland A Clark, Peter W Slane, Kirsty E Goodman, \\ Colin Feyerabend, John I Cater
}

\begin{abstract}
Background - Children with parents who smoke are often exposed to high levels of environmental tobacco smoke, and children with asthma are particularly susceptible to the detrimental effects of passive smoking. Data were collected from parents who smoke and from their asthmatic children. The families are currently taking part in a randomised controlled trial to test an intervention designed to reduce passive smoking in children with asthma. This paper reports on the baseline data. Questionnaire data and cotinine levels were compared in an attempt to assess exposure and to identify factors which influence exposure of the children. The aim of the study was to identify the scope for a reduction in passive smoking by these children.
\end{abstract}

Methods - A sample of 501 families with an asthmatic child aged 2-12 years was obtained. Factors influencing passive smoking were assessed by interviewing parents. Cotinine levels were measured from saliva samples using gas liquid chromatography with nitrogen phosphorous detection.

Results - Cotinine levels in children were strongly associated with the age of the child, the number of parents who smoked, contact with other smokers, the frequency of smoking in the same room as the child, and crowding within the home. Parental cotinine levels, the amount smoked in the home, and whether the home had a garden also exerted an independent effect on cotinine levels in the children.

Conclusions - Many children are exposed to high levels of environmental tobacco smoke and their cotinine levels are heavily dependent upon proximity to the parent who smokes. Parents who smoke have a unique opportunity to benefit their child's health by modifying their smoking habits within the home.

(Thorax 1997;52:766-769)

Keywords: passive smoking, asthma, children.

Passive smoking is responsible for respiratory morbidity including asthma in children. ${ }^{1-3}$ Some studies have found an increased incidence of asthma in the children of mothers who smoke. ${ }^{4-6}$ Others, although failing to show a causal effect, have demonstrated increased morbidity among asthmatic children, including a greater need for medication, more severe symptoms, impaired pulmonary function, and an earlier onset of the disease. ${ }^{7-9}$
Asthma is one of the most common reasons for children's consultations with the general practitioner, ${ }^{10}$ admissions to hospital, ${ }^{11}$ and issuing of prescriptions. ${ }^{6}$ It is estimated that approximately $50 \%$ of children under 10 years in this country have at least one parent who smokes. ${ }^{2}$ In addition, one paediatric respiratory outpatient clinic recently reported that $42 \%$ of children attending were regularly exposed to parental tobacco smoke in their own homes (Clark RA et al, unpublished data, 1996).

Families that include a child with asthma and at least one parent who smokes are currently taking part in a randomised clinical trial to test an intervention designed to reduce exposure of children with asthma to tobacco smoke. This paper reports on the extent of passive smoking, assessed by salivary cotinine levels, of the children at baseline and identifies factors that influence exposure. Factors investigated relate to the child, the index parent, other smokers in contact with the child, and the socioeconomic environment. The aim is to determine the scope for a possible reduction in passive smoking by the children.

\section{Methods}

STUDY POPULATION

The study was carried out in the Scottish regions of Tayside and Fife. As part of the randomised controlled trial, 501 families were recruited into the study between July 1994 and October 1995 from 73 GP practices. Families studied had a child with asthma aged 2-12 years and at least one parent who smoked. Criteria for admission were a documented diagnosis of asthma in the GP case records and at least one prescription for asthma medication in the preceding six months. Written permission was obtained from all the parents and also from the children where appropriate for age.

Data collection was undertaken by two research nurses (LI and KG) who visited families at home. Families were identified by GP practice staff. The index child was the youngest family member with asthma. Where both parents fitted the entry criteria, the index parent was the one available at the time of the interview. Saliva samples were collected from the index parent and the child at the time of the interview.

\section{QUESTIONNAIRE}

A questionnaire was completed by interview in the home by the index parent. This parent was a smoker, lived with the child, and was 
registered with the same GP practice as the child. Detailed information on family demography, the child's history of asthma, smoking habits of the index parent, and overall exposure of the child to tobacco smoke was collected. Social class was based on employment of the head of the household using the OPCS classification. ${ }^{12}$ Those in employment were classed as non-manual or manual workers due to the low number of families recruited from social classes I and II. In addition there was an unclassified group consisting of the unemployed and housewives/husbands.

\section{SALIVARY COTININE LEVELS}

Saliva samples to measure levels of cotinine, the major metabolite of nicotine, were obtained from the children and their parents to assess the children's levels of passive smoking and active smoking in parents. This widely used method has been shown to quantify passive and active smoking. ${ }^{13}$ Subjects were asked to collect saliva by saturating a dental roll in the mouth. The dental roll was transferred from the mouth into a syringe and the saliva expressed into a sterile plastic bottle. Samples were transported frozen to the Nicotine Laboratory, London for assay using their specific gas liquid chromatographic method that has a sensitivity of $0.1 \mathrm{ng} / \mathrm{ml} .^{13}$

Table 1 Childhood factors influencing salivary cotinine levels in children (one way ANOVA)

\begin{tabular}{lrlllc}
\hline & No. & $\begin{array}{l}\text { Geometric mean } \\
(\mathrm{ng} / \mathrm{ml})\end{array}$ & DF & $F$ & $p$ value \\
\hline Sex & & & & & \\
$\quad$ Boys & 316 & 2.73 & 1 & 2.43 & 0.12 \\
$\quad$ Girls & 176 & 3.16 & & & \\
Age of child (years) & 56 & 5.14 & 4 & 15.26 & $<0.0001$ \\
$\quad 2-3$ & 50 & 4.92 & & & \\
4 & 167 & 3.05 & & & \\
$5-7$ & 145 & 2.14 & & & \\
$8-10$ & 74 & 2.02 & & & \\
$11-12$ & & & &
\end{tabular}

Table 2 Influence of contact with smokers on salivary cotinine levels in children (one way $A N O V A$ )

\begin{tabular}{|c|c|c|c|c|c|}
\hline & No. & $\begin{array}{l}\text { Geometric mean } \\
(\mathrm{ng} / \mathrm{ml})\end{array}$ & $D F$ & $F$ & $p$ value \\
\hline \multicolumn{6}{|c|}{$\begin{array}{l}\text { Total amount smoked by } \\
\text { index parent (cigarettes per day) }\end{array}$} \\
\hline$<10$ & 69 & 2.03 & 3 & 3.92 & 0.009 \\
\hline $10-19$ & 264 & 2.90 & & & \\
\hline $20-29$ & 133 & 3.23 & & & \\
\hline$\geq 30$ & 26 & 3.69 & & & \\
\hline \multicolumn{6}{|c|}{ Index parent cotinine level $(\mathrm{ng} / \mathrm{ml})$} \\
\hline$<200$ & 77 & 2.27 & 4 & 3.97 & 0.004 \\
\hline $200-299$ & 103 & 2.51 & & & \\
\hline 300-399 & 127 & 2.74 & & & \\
\hline $400-499$ & 101 & 3.28 & & & \\
\hline$\geq 500$ & 84 & 3.88 & & & \\
\hline \multicolumn{6}{|c|}{$\begin{array}{l}\text { Amount smoked in the home by } \\
\text { index parent (cigarettes per day) }\end{array}$} \\
\hline $0-5$ & 119 & 1.70 & 4 & 14.62 & $<0.0001$ \\
\hline $6-10$ & 215 & 2.99 & & & \\
\hline $11-15$ & 89 & 3.82 & & & \\
\hline $16-20$ & 54 & 4.11 & & & \\
\hline$>20$ & 15 & 5.50 & & & \\
\hline \multicolumn{6}{|c|}{$\begin{array}{l}\text { Frequency of index parent smoking } \\
\text { in the same room as the child }\end{array}$} \\
\hline Never & 53 & 1.43 & 3 & 18.90 & $<0.0001$ \\
\hline Occasionally & 135 & 2.28 & & & \\
\hline Often & 51 & 2.83 & & & \\
\hline Every day & 253 & 3.78 & & & \\
\hline \multicolumn{6}{|l|}{ Partner smoking in the home } \\
\hline Single parent & 116 & 3.89 & 2 & 54.56 & $<0.0001$ \\
\hline Partner does not smoke & 177 & 1.62 & & & \\
\hline Partner smokes & 199 & 4.02 & & & \\
\hline \multicolumn{6}{|c|}{ Contact with smokers other than parents } \\
\hline No & 228 & 2.06 & 1 & 51.85 & $<0.0001$ \\
\hline Yes & 264 & 3.84 & & & \\
\hline
\end{tabular}

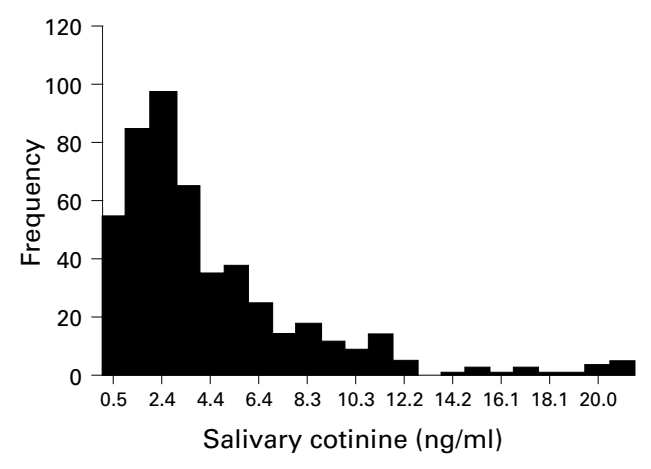

Figure 1 Salivary cotinine levels in children.

DATA ANALYSIS

Data were analysed using the SPSS for Windows package. The logarithm of the cotinine concentrations in the children was used in the analysis as the cotinine values were highly skewed. $t$ tests and multivariate analysis of variance (ANOVA) were used to identify which factors exerted a significant independent effect on cotinine levels in the children.

Complete data sets were obtained from 497 families. Five children with salivary cotinine levels above $35 \mathrm{ng} / \mathrm{ml}$ were excluded from the analysis. Those excluded had substantially higher cotinine levels than all of the other children. They included a boy aged three years (cotinine level $44.3 \mathrm{ng} / \mathrm{ml}$ ), a girl aged 4 years 8 months (cotinine level $31.3 \mathrm{ng} / \mathrm{ml}$ ), a boy aged 6 years 7 months (cotinine level $65.4 \mathrm{ng} /$ $\mathrm{ml}$ ), a boy aged 8 years 2 months (cotinine level $35.8 \mathrm{ng} / \mathrm{ml}$ ), and a girl aged 10 years 2 months (cotinine level $45.2 \mathrm{ng} / \mathrm{ml}$ ). All of these children were regularly exposed to at least four smokers but, owing to the exceptionally high cotinine levels, were excluded from the analysis. The results reported here are therefore based on data from 492 families.

\section{Results}

The mean age of the children was 7.6 years (range 2-12), and $316(64.2 \%)$ were boys. Salivary cotinine levels ranged from a nondetectable level (coded as $0.05 \mathrm{ng} / \mathrm{ml}$ ) to $21.2 \mathrm{ng} / \mathrm{ml}$ with an arithmetic mean of $4.35 \mathrm{ng} /$ $\mathrm{ml}$ (fig 1).

Several studies have used a salivary cotinine level of $14.3 \mathrm{ng} / \mathrm{ml}$ as a cut off point, above which it is assumed that the child must be actively smoking ${ }^{1415}$ based on a study in nonsmoking adolescents and adults. ${ }^{16}$ In this study 18 children had levels between $14.3 \mathrm{ng} / \mathrm{ml}$ and $21.2 \mathrm{ng} / \mathrm{ml}, 13$ of whom were five years or younger. The young age of these children makes it highly unlikely that they could have been actively smoking, so they were included in the study.

The mean age of the index parents was 33.5 years (range $19-53$ years); $76.2 \%$ (273 women, 102 men) were married and $23.8 \%$ (113 women, four men) were single. Parental cotinine levels ranged from $0.2 \mathrm{ng} / \mathrm{ml}$ (an occasional smoker) to $877 \mathrm{ng} / \mathrm{ml}$ with a mean (SD) of $357.9(155.4) \mathrm{ng} / \mathrm{ml}$. 
Table 3 Socioeconomic factors influencing salivary cotinine levels in children (one way ANOVA)

\begin{tabular}{|c|c|c|c|c|c|}
\hline & No. & $\begin{array}{l}\text { Geometric mean } \\
(\mathrm{ng} / \mathrm{ml})\end{array}$ & $D F$ & $F$ & $p$ value \\
\hline \multicolumn{6}{|c|}{ Education attainment of head of household } \\
\hline Professional qualification & 77 & 2.20 & 1 & 6.87 & 0.009 \\
\hline High school & 414 & 3.04 & & & \\
\hline \multicolumn{6}{|l|}{ Social class } \\
\hline Non-manual & 102 & 1.97 & 2 & 15.55 & $<0.0001$ \\
\hline Manual & 250 & 2.80 & & & \\
\hline Unemployed/housewives & 140 & 3.98 & & & \\
\hline \multicolumn{6}{|l|}{ Persons per room } \\
\hline$<1$ & 117 & 2.19 & 2 & 9.97 & $<0.0001$ \\
\hline 1 & 173 & 2.67 & & & \\
\hline$>1$ & 202 & 3.59 & & & \\
\hline \multicolumn{6}{|l|}{ Housing tenure } \\
\hline Privately owned & 187 & 1.98 & 1 & 45.43 & $<0.0001$ \\
\hline Rented & 305 & 3.62 & & & \\
\hline \multicolumn{6}{|l|}{ Having a garden } \\
\hline Yes & 401 & 2.62 & 1 & 19.80 & $<0.0001$ \\
\hline No & 91 & 4.36 & & & \\
\hline
\end{tabular}

Table 4 Factors exerting an independent significant effect on salivary cotinine level of children

\begin{tabular}{|c|c|c|c|}
\hline & $\begin{array}{l}\text { Parameter estimates } \\
\text { (change relative to } \\
\text { first value, } \mathrm{ng} / \mathrm{ml} \text { ) }\end{array}$ & $F$ & $\begin{array}{l}\text { Significance } \\
\text { of } F\end{array}$ \\
\hline Age of child (years) & & 21.30 & $<0.0001$ \\
\hline $2-3$ & - & & \\
\hline 4 & -0.27 & & \\
\hline $5-7$ & -0.62 & & \\
\hline $8-10$ & -0.88 & & \\
\hline $11-12$ & -1.06 & & \\
\hline Index parent cotinine level & & 4.22 & 0.002 \\
\hline$<200$ & - & & \\
\hline $200-299$ & 0.06 & & \\
\hline $300-399$ & 0.14 & & \\
\hline $400-499$ & 0.32 & & \\
\hline$\geq 500$ & 0.40 & & \\
\hline $\begin{array}{l}\text { Amount smoked in the home by } \\
\text { index parent (cigarettes per day) }\end{array}$ & & 3.69 & 0.006 \\
\hline $0-5$ & - & & \\
\hline $6-10$ & 0.23 & & \\
\hline $11-15$ & 0.44 & & \\
\hline $16-20$ & 0.36 & & \\
\hline$>20$ & 0.36 & & \\
\hline $\begin{array}{l}\text { Frequency of index parent smoking } \\
\text { in the same room as the child }\end{array}$ & & 6.41 & $<0.0001$ \\
\hline Never & - & & \\
\hline Occasionally & 0.35 & & \\
\hline Often & 0.51 & & \\
\hline Every day & 0.56 & & \\
\hline Partner smoking & & 33.41 & $<0.0001$ \\
\hline Single parent & - & & \\
\hline Partner does not smoke & -0.04 & & \\
\hline Partner smokes & 0.65 & & \\
\hline Contact with other smokers & & 23.82 & $<0.0001$ \\
\hline Yes & - & & \\
\hline No & -0.36 & & \\
\hline Persons per room & & 9.30 & $<0.0001$ \\
\hline$<1$ & - & & \\
\hline 1 & 0.27 & & \\
\hline$>1$ & 0.41 & & \\
\hline Having a garden & & 8.64 & 0.003 \\
\hline Yes & - & & \\
\hline No & 0.28 & & \\
\hline
\end{tabular}

Passive smoking in the children was assessed by comparing their cotinine levels with questionnaire data. Factors influencing cotinine levels in the children looked at three areas: the child, contact with smokers, and socioeconomic factors.

THE CHILD

The age of the child was a powerful determinant of salivary cotinine levels (table 1 ). There was a stepwise reduction in cotinine levels with ascending age. The largest reduction was detected between the preschool four year olds and those aged 5-7 years. Boys had lower cotinine levels than girls but this failed to reach significance in this study.
CONTACT WITH SMOKERS

There was a strong relationship between salivary cotinine levels in the children and parental smoking. Cotinine levels in the children increased from families in which only the father smoked (geometric mean $0.99 \mathrm{ng} / \mathrm{ml}$ ) to those where only the mother smoked (geometric mean $3.12 \mathrm{ng} / \mathrm{ml}$ ), to those where both parents smoked (geometric mean $4.02 \mathrm{ng} / \mathrm{ml}$ ). The four children who had non-detectable levels of salivary cotinine came from families where only the father smoked.

Accurate details on smoking habits could only be obtained from the index parent. Parameters of the index parent's smoking which were significant were cotinine levels, the total number of cigarettes smoked, the amount smoked in the home, and the frequency of smoking in the same room as the child. Regular contact with smokers other than parents also had an effect on child cotinine levels (table 2).

SOCIOECONOMIC FACTORS

Social class had an effect on cotinine levels, as did educational attainment of the head of the household. Families living in rented accommodation had higher cotinine levels than those in privately owned housing. An index of crowding previously described by Jarvis et al was obtained for each family. ${ }^{14}$ This is calculated by dividing the number of people sharing the home by the number of rooms in the home (excluding the kitchen and bathrooms). Three levels are used to describe the study population: low (less than one person per room), medium (one person per room), and high (more than one person per room). Crowding was associated with higher cotinine levels, and having a garden was associated with lower child cotinine levels (table 3 ). The effect of having a garden was still significant after controlling for all the social factors (data not shown).

All of the factors which were significant in the univariate analyses were fitted into an ANOVA model. Those factors emerging as exerting a significant independent effect were age of the child, parental cotinine levels, the amount smoked in the home by the index parent, frequency of smoking in the same room as the child, smoking by the non-index parent in the home, contact with smokers other than parents, crowding within the home, and having a garden (table 4). Overall the model explains $46 \%$ of the variance in the children's cotinine levels.

Of the factors which remained significant in the multivariate model, parameter estimates were calculated for each of the covariates relative to the first value displayed in the table (table 4). These show a clear trend in persistence of cotinine levels for age of the child and parental smoking. They also show that having a partner who smokes is a powerful factor.

\section{Discussion}

This study has shown that many children with asthma whose parents smoke are exposed to 
high levels of tobacco smoke. These levels give cause for concern in this group of children with asthma. Previous studies have shown impaired pulmonary function in normal children ${ }^{1517}$ and children with asthma ${ }^{18}$ regularly exposed to tobacco smoke (as assessed by cotinine levels). One of the studies has shown a $6 \%$ reduction in pulmonary function in children with salivary cotinine levels above $4.1 \mathrm{ng} / \mathrm{ml} .^{15}$ In our study $37 \%$ of the children had cotinine levels above $4 \mathrm{ng} / \mathrm{ml}$, with $15 \%$ of them having levels above $8 \mathrm{ng} / \mathrm{ml}$, twice the level shown to affect pulmonary function. Children with symptomatic asthma whose airways are already inflamed and hyperreactive are likely to be at greater risk of respiratory impairment.

Substantially higher levels of cotinine occurred in the youngest children. This effect of age has previously been reported in a study of children using urinary cotinine levels as a marker of exposure ${ }^{19}$ Higher levels of cotinine might have been expected in older children, partly because they will still be awake in the evenings when parents are at home and able to smoke. Furthermore, although all children were reported to be non-smokers, some of the older children could have been occasional smokers. The effect of age could be explained by the younger children spending more time in close proximity to their smoking parents. This is substantiated by the large decrease in mean cotinine levels between the preschool children and those aged 5-7 years.

Cotinine levels of the children were higher if the index parent was female. The stepwise increase in child cotinine levels from father only smoking to mother only smoking to both parents smoking, demonstrated in a number of studies, ${ }^{81920}$ was apparent in this study. This probably relates to the amount of time the mother spends with the children in the home. Fathers tend to spend less time in the home and to smoke less at home.

As would be expected, the amount which parents smoke was a major determinant of the cotinine levels in the children. The amount smoked by parents was assessed by parental reporting and parental cotinine levels. This is the first study to report the relationship between child and parental cotinine levels. What is interesting is how, in the final statistical model, three separate aspects of smoking by the index parent exerted independent significant effects. It is not just how much the parent smokes as assessed by parental cotinine levels - but how much they smoke in the home and the frequency of smoking in front of the child. The extent of exposure to other smokers also contributes significantly to the children's cotinine levels. Studies on passive smoking in children need to take account of these factors to obtain accurate estimates of passive smoking.

Social class and educational attainment of the head of the household, which were important in the univariate analysis, failed to make a contribution to child cotinine levels when other factors were taken into account. Crowding within the home, independently of housing tenure or social class, was associated with higher cotinine levels in the children, an effect previously reported. ${ }^{14}$ Having a garden reduces the exposure of the child, either because the parents use the garden to smoke away from the children or because children with access to a garden, even at a young age, spend less time within the confines of the home.

The conclusion from these results is that it is proximity to smoking adults which determines passive exposure of the children. In many ways this is not surprising; what is impressive is the strength and consistency of the effect. Parents should be aware of the factors which influence the exposure of their children and the impact which environmental tobacco smoke has on asthma. It may be possible to reduce the passive smoking by these children by encouraging parents to take steps to protect their children from environmental tobacco smoke. A definite answer will only be obtained by a randomised clinical trial of the benefits of giving this advice to parents. Such a study, funded by The Wellcome Trust, is currently underway.

The study was funded by The Wellcome Trust (grant number 039282). We gratefully acknowledge the assistance of the general practitioners and their staff from the 73 practices in Tayside and Fife who assisted in identifying families suitable for this and Fife.

1 Charlton A. Children and passive smoking: a review. $\mathcal{F}$ Family Pract 1994;38:267-77.

2 Couriel JM. Passive smoking and the health of children. Thorax 1994;49:731-4.

3 Stoddard J, Miller T. Impact of parental smoking on the prevalence of wheezing respiratory illness in children. $A m$ $\mathcal{F}$ Epidemiol 1995;141:96-102.

4 Martinez FD, Cline M, Burrows B. Increased incidence of asthma in children of smoking mothers. Pediatrics 1992; 89:21-6.

5 Weitzman M, Gortmaker S, Walker DK, Sobol A. Maternal smoking and childhood asthma. Pediatrics 1990;85:50511 .

6 Lenney W, Wells NEJ, O'Neill BA. Burden of paediatric asthma. Eur Respir Rev 1994;4:49-62.

7 Ehrlich R, Kattan M, Godbold J, Saltzberg DS, Grimm $\mathrm{KT}$, Landrigan PJ, et al. Childhood asthma and passive smoking, urinary cotinine as a biomarker of exposure. $A m$ Rev Respir Dis 1992;145:594-9.

8 Willers S, Svenonius E, Skarping G. Passive smoking and childhood asthma. Allergy 1991;46:330-4

9 Bakoula CG, Kafritsa YJ, Kavadias GD, Lazopoulou DD, Theodoridou MC, Maravelias KP, et al. Objective passivesmoking indicators and respiratory morbidity in young children. Lancet 1995;346:280-1.

10 Anderson HR. Epidemiology of asthma. Br $\mathcal{f}$ Hosp Med 1992;47:99-103.

11 Kun HY, Oates RK, Mellis CM. Hospital admissions for asthma - a true increase? Med f Aust 1993;159:312-3.

12 Office of Population Census and Surveys. Classification of occupations 1st edn Census

13 Feyerabend C, Russell MAH. A rapid gas-liquid chromatographic method for the determination of cotinine and matographic method for the determination of cotinine and nicotine

14 Jarvis MJ, Strachan DP, Feyerabend C. Determinants of passive smoking in children in Edinburgh, Scotland. Am f Publ Health 1992;82:1225-9.

15 Cook DG, Whincup PH, Papacosta O, Strachan DP, Jarvis MJ, Bryant A. Relation of passive smoking as assessed by salivary cotinine concentration and questionnaire to spirometric indices in children. Thorax 1993;48:14-20.

16 McNeill AD, Jarvis MJ, West R, Russell MAH, Bryant A Saliva cotinine as an indicator of cigarette smoking in adults. Br f Addiction 1987;82:1355-60.

17 Strachan DP, Jarvis MJ, and Feyerabend C. The relationship of salivary cotinine to respiratory symptoms, spirometry and exercise-induced bronchospasm in seven year old children. Am Rev Respir Dis 1990;142:147-51.

18 Chilmonczyk BA, Salmun LM, Megathlin KN, Neveux LM, Palomaki GE, Knight GJ, et al. Association between exposure to environmental tobacco smoke and exexposure to environmental tobacco smoke and ex-
acerbations of asthma in children. $N$ Engl f Med 1993; 328: $1665-9$.

19 Reese AC, James IR, Landau LI, Lesouef PN. Relationship between urinary cotinine levels and diagnosis in children admitted to hospital. Am Rev Respir Dis 1992;146:66-70.

20 Jarvis MJ, Russell MAH, Feyerabend C, Eiser JR, Morgan M, Gammage P, et al. Passive exposure to tobacco smoke: saliva cotinine concentrations in a representative population of non-smoking schoolchildren. $B M \mathcal{F} 1985 ; 291$ 927-9. 